\title{
Tannin quantification and chemical-energetic characterization of biomass residues of Bertholletia spp. and Lecythis' spp. fruits
}

\author{
Quantificação de tanino e caracterização \\ química-energética de resíduos de biomassa \\ de frutos de Bertholletia spp. e Lecythis'spp.
}

\author{
Iara Nobre Carmona ${ }^{1}$, Juliane da Silva Sampaio ${ }^{2}$, \\ Pablo Antônio Souza Amorim da Luz ${ }^{2}$, Fernando Wallase Carvalho Andrade ${ }^{2,3}$
}

\footnotetext{
${ }^{1}$ Programa de Pós-Graduação em Ciência e Tecnologia da Madeira, CTM/UFLA, Pc Prof. Edmir Sa Santos s/n, CEP: 37200-000, Lavras, Minas Gerais, Brasil.

${ }^{2}$ Universidade Federal do Oeste do Pará, LTM/UFOPA, Rua Vera Paz s/n, CEP: 68030-000, Salé, Santarém, Pará, Brasil.

${ }^{3}$ Universidade Estadual Paulista, Dep. Ciência Florestal, Rua Dr. Jose Barbosa de Barros s/n, CEP: 18610-034, Jd. Paraíso, Botucatu, São Paulo, Brasil.

e-mail: iaranobrecarmona@gmail.com,julianesampaio22@gmail.com, pdaluz19@gmail.com, engenheiro.fernandoandrade@gmail.com
}

\begin{abstract}
Biomass residues originated from agroforestry systems has been demonstrating great usage potential for the pharmaceutical, textile and energy industries. In the Amazon region, the use of these materials can stimulate the sustainable economic development of extractive communities and agroforestry systems. However, for a better use of this material, it is necessary to quantify and qualify the chemical components present in these residues. Keeping that in mind, our research aimed to quantify the presence of condensed and hydrolysable tannins, and to chemically and energetically characterize the Bertholletia excelsa and Lecythis pisonis' fruit residues, with the intent to assess the usage potential for this biomass resource in different industries. The studied material was collected from local extractives and merchants. Tannin quantification was performed through thin layer chromatography (TLC) method and the total values of extractives, lignin and holocellulose were also quantified. The energy potential was determined by the variables of apparent density, gravimetric yield, superior calorific power and charcoal's immediate chemistry (the charcoal was produced at $450{ }^{\circ} \mathrm{C}$ ). The associations between variables were determined by a linear correlation. The TLC for condensed tannin was positive for $B$. excelsa. As for the TLC of hydrolysable tannins, the results were negative for both materials. The high levels of lignin and extractives in fruit's residues of both species demonstrate the energy potential of this material. Our results may favor the use of $B$. excelsa's residues for the production of polymers and adhesives, as well as other non-wood residues with high content of lignin, fixed carbon and calorific power in energetic products.
\end{abstract}

Keywords: Bertholletia excelsa; Lecythis pisonis; Brazillian chestnut; tannins; biomass residues from agroforestry systems.

\section{RESUMO}

Resíduos de biomassa oriundos de sistemas agroflorestais têm demonstrado grande potencial de uso pelas indústrias farmacêutica, têxtil e de energia. Na região amazônica, o uso desses materiais pode estimular o desenvolvimento econômico sustentável de comunidades extrativistas e sistemas agroflorestais. Porém, para um melhor aproveitamento desse material, é necessário quantificar e qualificar os componentes químicos presentes nesses resíduos. Tendo isso em mente, nossa pesquisa teve como objetivo quantificar a presença de taninos condensados e hidrolisáveis e caracterizar química e energeticamente os resíduos de frutas de Bertholletia excelsa e Lecythis pisonis, com o intuito de avaliar o potencial de uso deste recurso de biomassa em diferentes indústrias. O material estudado foi coletado de extrativistas e comerciantes locais. A quantificação dos taninos foi realizada através do método de cromatografia em camada delgada (CCD) e os valores totais 
de extrativos, lignina e holocelulose também foram quantificados. O potencial energético foi determinado pelas variáveis de densidade aparente, rendimento gravimétrico, poder calorífico superior e química imediata do carvão (o carvão foi produzido a $450{ }^{\circ} \mathrm{C}$ ). As associações entre as variáveis foram determinadas por uma correlação linear. A CCD para tanino condensado foi positiva para B. excelsa. Quanto à CCD dos taninos hidrolisáveis, os resultados foram negativos para ambos os materiais. Os altos níveis de lignina e extrativos nos resíduos das frutas de ambas as espécies demonstram o potencial energético deste material. Nossos resultados podem favorecer a utilização de resíduos de $B$. excelsa para a produção de polímeros e adesivos, bem como outros resíduos não lenhosos com alto teor de lignina, carbono fixo e poder calorífico em produtos energéticos.

Palavras-chave: Bertholletia excelsa; Lecythis pisonis; Castanha brasileira; taninos; resíduos de biomassa de sistemas agroflorestais.

\section{INTRODUCTION}

Forest biomass residues can be used for the production of medicines such as those used for hemostatic purposed and antidotes. It can also be used for leather material in the textile industry, where they use tannins, or even as feedstock fuel [1]. Agroforestry systems and extractive communities, that produces and extracts nuts, respectively, generate tons of biomass residues in the Amazon region, which has no proper usage. Most of the income of these communities come from nut harvesting, which lasts approximately six months per year. Using biomass residues from agroforestry systems and activities related to the extractivism as a raw material for different industrial purposes can aggregate value to this residue, transforming it into a product that can help solving this social problem, and generating more revenue throughout the years.

Bertholletia excelsa Humn. \& Bonpl, popularly known as Brazil's nut or "Castanheira-do-Pará" (name in Brazilian Portuguese) is a protected species according to Brazilian law 5975/2006 [2]. The specie is very well known for being one of the biggest trees in the Amazon rainforest [3]. Many families that live in the Amazon region practice the extractivism, being the collection of nuts from fruits of $B$. excelsa and Lecythis pisonis Cambess - both from family Lecythidaceae - one of the most important activities for the economy in the region. This, however, generates products of low added value.

The main residues originated from the cultivation and processing of Brazil's nut are the thick fruit shell (pericarp), a $\sim 2 \mathrm{~cm}$ thick spherical lignified shell (pyxidium) with a diameter of $10-12.5 \mathrm{~cm}$, that protects the seeds inside it from high falls and predators, and the seed's bark (teguments), which individually encloses the seeds and is also very thick and resistant [4]. For each ton of cleaned nuts, it is produced about 1.4 tons of residues (fruit shell and seed's tegument) [5]. That said, it is important to look for alternatives and possible uses for these co-products. In this context, phenolic compounds and its by-products, like the bioenergy that it can generate, can be of valuable use for this purpose.

In this context, the study of its chemical-energetic properties becomes of great importance [6]. Thus, the knowledge on biomass characteristics like its elemental chemical composition (carbon, hydrogen, oxygen), macromolecular composition (cellulose, lignin, hemicelluloses, extractives), density, moisture content and immediate chemical composition (volatile materials, fixed carbon and ashes) are essential for the best use of this residues as an energy source, since these characteristics influence its heating value [7, 8]. The mesocarp of Brazil nuts is characterized by a high lignin content $(\sim 58 \%)$ which provide high mechanical stability and resistance against microbial degradation [4]. High lignin content (>28\%) positively affects the gravimetric yields in charcoal, fixed carbon and contributes to the increase in energy generated by direct firewood burning [9].

Lignocellulosic residues, such as cashew stalk bagasse, have phenolic compounds, flavonoids, tannins, sugars and ascorbic acid in their nutritional composition, in addition to their lignocellulosic composition allowing the production of xylitol and ethanol [10]. The mesocarp of the green coconut, for example, is a material with potential for the extraction of tannin and for the manufacture of composites [11]. Charcoal made from $B$. excelsa's biomass residues also has characteristics such as low ash content and high heating value, comparable to the charcoal produced from the wood of other species and from non-wood products too [12].

However, to the best of our knowledge, there is no information on the scientific literature about tannin potential of Amazonian agroforestry residues or the energy potential of different types of residues generated by harvesting the $B$. excelsa and $L$. pisonis nuts. In addition, it is necessary to determine which biomass characteristic most influence the product quality, allowing a more appropriate potential assessment for these materials.

In this research we performed the chemical and energetic characterization of biomass residues of $B$. $e x$ - 
celsa and L. pisonis in order to evaluate possible potentials for tannin extraction and energy production. The results will allow us to compare the chemical-energetic characteristics between both residues, in natura and charcoal, which will help to indicate a better usage for them. Moreover, the correlations between the chemical and energetic variables may indicate the selection of most correlated variables for future studies on other agroforestry residues.

\section{MATERIAL AND METHODS}

\subsection{Collection and preparation of the material}

B. excelsa and L. pisonis fruits were collected from the main supply center of the lower Amazon river, called "Mercadão 2000 fair", in the city of Santarém, state of Pará, Brazil. The nuts were collected from the ground during the 2016 - 2017 harvest. We collected ten (10) fruit's shells for each species, and approximately one kilogram of seed's tegument of B. excelsa (Figure 1).

The collected residues were cleaned and carefully ground in a Willey mill machine to not overheat the knives due to hardness of shell fruits, which could influence the chemical composition of the raw material. We used the material that passed the 40 mesh sieve $(1.00 \mathrm{~mm})$ and retained on the 60 mesh $(0.25 \mathrm{~mm})$. This material was conditioned in a room at $21^{\circ} \mathrm{C}$ and $65 \%$ relative humidity.

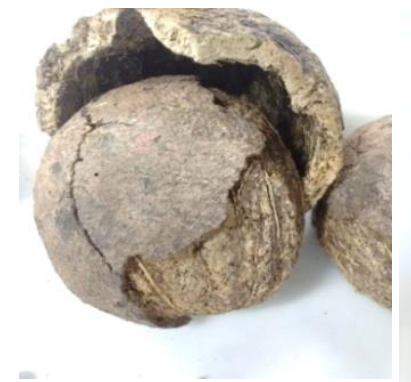

(a)

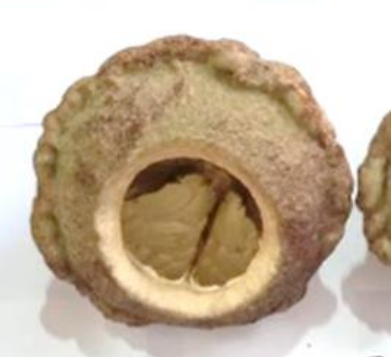

(b)

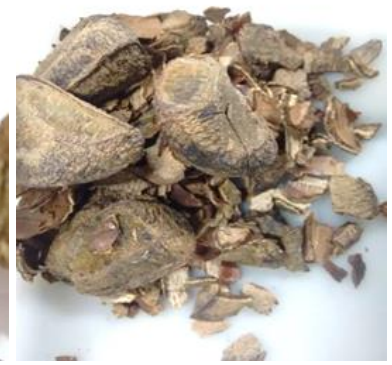

(c)

Figure 1: In natura biomass residues of Bertholletia excelsa's fruit (a), Lecythis pisonis' fruit (b) and Bertholletia excelsa's tegument (c).

From the homogenized milled residue of each test material, we used triplicates for analyzing the chemistry and immediate chemical composition of the material.

\subsection{Tannin quantification using Thin Layer Chromatography (TLC) method}

For the quantification of condensed tannins, about $1 \mathrm{~g}$ of the milled biomass residue of each material was put under refluxe on a hot plate $\left(80-90{ }^{\circ} \mathrm{C}\right)$ of a soxhlet apparatus with approximately $75 \mathrm{ml}$ of ethanol for a 4hour period. After filtration and concentration of the extracts to about $1 \mathrm{~mL}, 10 \mu \mathrm{L}$ of the extracted solution of each material were applied to two chromatoplates, respecting the distance of $1.5 \mathrm{~cm}$ from each other; silica gel was used as adsorbent in the stationary phase while methyl acetate, in the proportion of 90:10, was used as eluent for the mobile phase. As a comparison method, we used the extracting solution of green tea [Camellia sinensis (L.) O. Kuntze] as the standard parameter for both plates, as the extracting solution of green tea has high concentration of both condensed and hydrolyzed tannins, it becomes easy to be seen in the chromatoplates.

To reveal the condensed tannin, we used a solution of vanillin $(15 \mathrm{~g}$ of vanillin, $250 \mathrm{~mL}$ of ethanol and $2.5 \mathrm{~mL}$ of $\mathrm{H}_{2} \mathrm{SO}_{4} 100 \%$ ). To reveal the hydrolysable tannin, we used a solution of $\mathrm{FeCl}_{3} / \mathrm{HCl} 1 \%$ followed by heating. The appearance of red and blue spots under visible light indicates the presence of condensed and hydrolysable tannins, respectively.

When ready, the chromatoplates were digitized and the retention factor (Rf) sample values and patterns were compared for the presence or absence of tannic acid. The retention factor $(\mathrm{Rf})$ is the ratio of the distance traveled by the evaluated material as a function of the mobile phase, being that the most important parameter in TLC evaluation. 


\subsection{Total extractives, lignin and holocellulose content}

The total extractives content was determined in a solution of ethanol:toluene [13]. The insoluble lignin content was determined according to [14]. The holocellulose content was obtained by difference.

\subsection{Charcoal analysis}

The oven-dried solid residues $\left(24 \mathrm{~h} ; 103 \pm 3^{\circ} \mathrm{C}\right)$ were carbonized in a cylindrical stainless-steel capsule in an electric oven (muffle) at a final temperature of $450{ }^{\circ} \mathrm{C}$, with a heating rate of $1.67{ }^{\circ} \mathrm{C} \cdot \mathrm{min}^{-1}$, during 30 minutes, according [15].

Before and after the carbonization process, the samples were weighted on an analytical balance (Shimadzu AUY220). The charcoal gravimetric yield was determined by mass percentage difference, between biomass and charcoal. Charcoal apparent density was obtained according to NBR 7190 [16].

The proximate analysis of charcoal was determined according to ASTM D1107 [17]. The moisture, volatile materials, ash and fixed carbon content of biomass and charcoal were calculated. The fixed carbon yield of the of the charcoal was obtained through the product of the charcoal gravimetric yield by the fixed carbon content divided by 100 . The high heating value (HHV) was determined in an calorimetric bomb (IKA, C200) following instructions from NBR 8633 [18].

\subsection{Statistical analysis}

We used a completely randomized design for tree materials, which of them had tree repetition for each one of the sixteen (16) variables, they are: moisture content, volatile material, ash, fixed carbon, and HHV for biomass and charcoal (10 variables); lignin, holocellulose and extractives for the biomass (3 variables); e lastly, gravimetric yield, apparent density and fixed carbon yield (3 variables).

Our null hypothesis was that no differences would be verified between materials for the evaluated variables. Boxplots were used to analyze the results in an exploratory way. Through the linear correlation verified by the Pearson's test, we could observe correlations between the chemical (independent variables) and energetic (dependent variables) characteristics. All analysis was performed in the statistical software R, version 3.2.1 [19]. The data of the Pearson's correlation test was interpreted as a function of the proximity of the coefficient value to one (in modulus) [20], as follows: $|\mathrm{r}|<0.20$, the correlation is negligible; $0.20<|\mathrm{r}|$ $<0.40$, weak correlation; $0.40<\mathrm{r} \mid<0.60$, moderate correlation; $0.60<\mathrm{r} \mid\langle 0.80$, strong correlation; $|\mathrm{r}|\rangle$ 0.80 , very strong correlation.

\section{RESULTS AND DISCUSSION}

\subsection{Tannins}

The chromatographic analysis performed with a thin layer of silica gel (TLC) is largely used in the pharmaceutical industry mainly because of its properties for identifying drugs, and its low cost. In the TLC method the components can move by using capillarity forces through the thin and uniform layer of the stationary phase, this happens at different speeds. In TLC with green tea (Rf's $=0.55 ; 0.60)$, used as a standard pattern, we could observe the presence of condensed tannins only in the fruit shell of $B$. excelsa (Rf's $=0.45 ; 0.75)$ (Figure 2a). In the TLC with standard green tea with Rf's of 0.50 and 0.55 , we did not observe the presence of hydrolysable tannins in none of the materials (Figure 2b). 


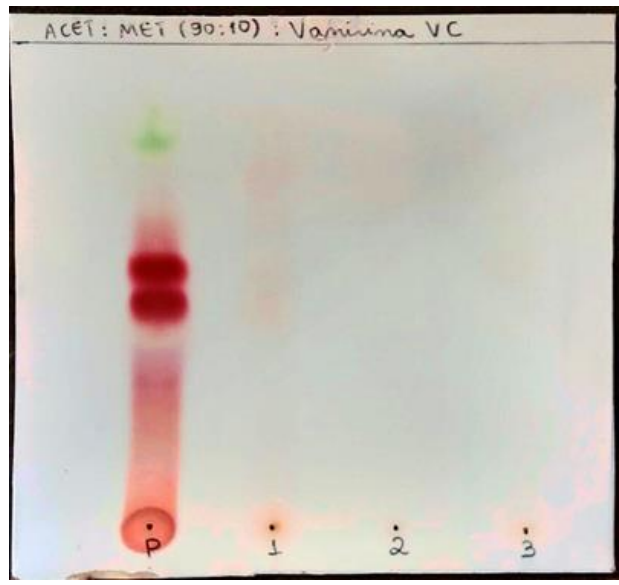

(a)

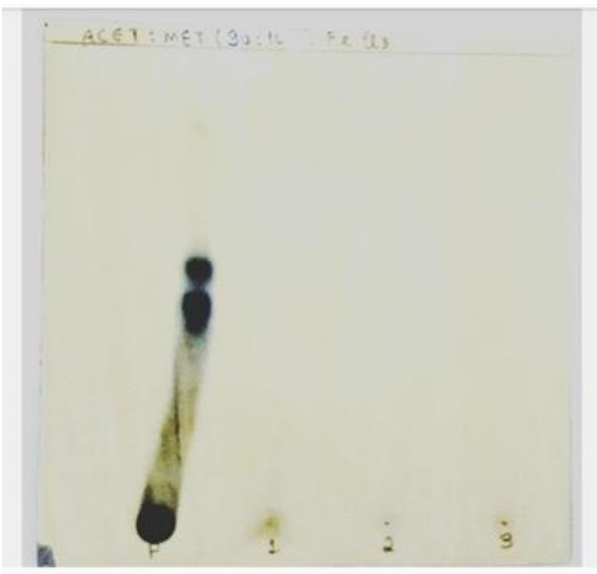

(b)

Figure 2: Chromatography of thin layer in silica-gel (TLC) with vanillin revelator for condensed tannins (on the left), and of $\mathrm{FeCl}_{3} / \mathrm{HCl}$ for hydrolysable tannins, with green tea [Camellia sinensis (L.) O. Kuntzel], as standard pattern, for the materials 1, 2 and 3 (Bertholletia excelsa's shell, and tegument and Lecythis pisonis' shell, respectively).

In general, fruits with elevated seed percentage may contain high tannin content as well, because those have high concentration of tannin acids in its tegument [21]. It is believed that the plant uses a strategy in which the tannins are directed from the peel to the fruits, thus avoiding the attack of predators. However, we did not observe the presence of tannic compounds in the tegument of B. excelsa, this may have happened because the samples were collected in a market, whose seeds were already ripe and probably lost some of their chemical potential.

A qualitative pattern similar to the results found in this work has been seen by VÁSQUEZ et al. [22] when evaluating the potential of the extracts from the shell of Castanea sativa, in which the tannic compounds were condensed. The condensed tannins are also known as proanthocyanidins, and are distributed into many different vegetal families, generally in woody plants. They are used in the fabrication of polymers and resins [23]. These polymers are largely used for treating supply and residual water [24, 25], in the fabrication of paints and adhesives for wood and derivatives [26], being this way, a potential use for the residue of B. excelsa's fruits.

The literature has reports of many different ways of determining tannins, as an example the protein precipitation assays [27, 28]. However, there is no ideal method, although the colorimetric methods are the ones most used for this kind of analysis $[29,30]$. The TLC method has a lower cost when compared to the others above, and this was critical when deciding to use it on our study. It was effective in detecting the presence of tannins, and we recommend its use for similar studies.

Due to the great chemical diversity of the phenolic compounds, which originate the tannins, different solvents are used in the extraction process, as well as different methodologies are used in the process of quantifying these compounds [31]. In the methodology used for condensed tannins, both leucoanthocyanidins and proanthocyanidins react with vanillin in the presence of $\mathrm{HCl}$ to produce a red condensed product, which is spectrophotometrically detected [32]. One of the hypotheses is that the B. excelsa's fruit shell is poor in leucoanthocyanidins, leading to a less intense red color and compromising the quantity of condensed tannins adhered to the chromatoplate.

ROCHA et al. [33] when evaluating phenolic compounds and condensed tannins in fruits of Cerrado - a Brazilian biome - observed that acetone $70 \%$ has better efficiency for extracting these compounds when compared to ethanol $95 \%$. There is no information in the scientific literature of methodologies for extracting tannins from fruit's shell. In this sense, we are conducting new studies to improve the extraction and quantification method of tannins for this type of residue.

A factor that could be related to the low or high presence of tannins, as observed lately, is the phenophase in which the plant is. AZEVÊDO et al [34] when studying the condensed tannins in the bark of $M i$ mosa tenuiflora could conclude that the highest level of this substances could be seen with the higher presence of green leaves. Therefore, knowing the physiological conditions of the plants it is possible to identify the real motives that led the plants to have low or high quantity of tannic substances in a determined period of time and determined part of the plant (root, wood, bark, fruit, leaf). Future studies that would evaluate the 
effect of the phenophase in the quantity of tannins both in the leaf and nuts fruits from Amazon can contribute better in this sense.

\subsection{Chemical-energetic characterization}

The tegument of B. excelsa has shown the highest lignin content between the evaluated materials (Table 1). This value is considered elevated when compared to Eucalyptus's wood, which has mean lignin content of 26.1 and $30.3 \%$ [35]. Lignin can have a strong influence in the energetic usage of the biomass [36, 37]. Besides that, different chemical products of high aggregated value can be produced from the aromatic structure of the lignin [38], such as carbon fibers, polymer modifiers, adhesives, resins, among others.

Table 1: Average and standard deviation* from chemical-energetic variables from biomass and charcoal from fruit shell (S) and tegument $(\mathrm{T})$ of Bertholletia excelsa and Lecythis pisonis.

\begin{tabular}{|c|c|c|c|c|}
\hline \multirow{3}{*}{ Material } & \multirow{3}{*}{ VARIABLE } & \multicolumn{3}{|c|}{ MATERIAL } \\
\hline & & B. excelsa $\mathbf{S}$ & B. excelsa $\mathbf{T}$ & L. Pisonis $\mathbf{S}$ \\
\hline & & Average & Average & Average \\
\hline \multirow{8}{*}{ Biomass } & Lignin content $(\%)$ & $27.64^{(1.10)^{*}}$ & $51.40^{(1.32)^{*}}$ & $23.30^{(0.39)^{*}}$ \\
\hline & Holocellulose $(\%)$ & $57.27^{(1.11)}$ & $33.94^{(1.54)}$ & $56.56^{(0.34)}$ \\
\hline & Alcohol:toluene extractives (\%) & $14.56^{(0.10)}$ & $12.83^{(0.26)}$ & $16.97^{(0.25)}$ \\
\hline & Moisture content $(\%)$ & $11.54^{(0.21)}$ & $14.96^{(0.32)}$ & $13.01^{(0.09)}$ \\
\hline & Volatile materials content $(\%)$ & $76.61^{(0.23)}$ & $67.80^{(0.36)}$ & $72.61^{(0.06)}$ \\
\hline & Ash content $(\%)$ & $0.53^{(0.09)}$ & $1.83^{(0.08)}$ & $3.17^{(0.04)}$ \\
\hline & Fixed carbon content $(\%)$ & $22.87^{(0.22)}$ & $30.37^{(0.43)}$ & $24.22^{(0.09)}$ \\
\hline & High heating value $\left(\mathrm{kcal}^{\mathrm{kg}}{ }^{-1}\right)$ & $3934.14^{(17.52)}$ & $4537.53^{(34.34)}$ & $4040.82^{(7.02)}$ \\
\hline \multirow{8}{*}{ Charcoal } & Moisture content (\%) & $2.87^{(0.06)}$ & $3.45^{(0.06)}$ & $4.05^{(0.22)}$ \\
\hline & Volatile materials content $(\%)$ & $18.27^{(0.53)}$ & $17.70^{(0.72)}$ & $21.23^{(1.35)}$ \\
\hline & Ash content $(\%)$ & $2.57^{(0.01)}$ & $5.24^{(0.18)}$ & $6.13^{(0.26)}$ \\
\hline & Fixed carbon content $(\%)$ & $79.16^{(0.54)}$ & $77.05^{(0.89)}$ & $72.63^{(1.17)}$ \\
\hline & High heating value (kcal. $\mathrm{kg}^{-1}$ ) & $6694.77^{(43.96)}$ & $6521.78^{(72.84)}$ & $6160.69^{(95.05)}$ \\
\hline & Charcoal gravimetric yield (\%) & $34.75^{(0.28)}$ & $44.52^{(0.85)}$ & $34.55^{(2.15)}$ \\
\hline & Apparent density $\left(\mathrm{g} \cdot \mathrm{cm}^{-3}\right)$ & $0.41^{(0.01)}$ & $0.32^{(0.01)}$ & $0.44^{(0.01)}$ \\
\hline & Fixed Carbon yield (\%) & $27.51^{(0.40)}$ & $34.31^{(1.02)}$ & $25.09^{(1.49)}$ \\
\hline
\end{tabular}

The energetic use of biomass is highly influenced by its chemical composition, such as cellulose, holocellulose and lignin content. The wood thermal degradation is less, the greater its lignin content, which increases its yield with the coproducts from pyrolysis, like charcoal and pyroligneous extract. While holocellulose (hemicellulose + cellulose) is degraded between 150 to $400{ }^{\circ} \mathrm{C}$ [39], the lignin is more thermal stable, and maintain its structure to up to $900{ }^{\circ} \mathrm{C}[40,41]$, as observed for the yield in charcoal from $B$. excelsa's fruit tegument.

We have observed high content of total extractives for all three studied residues (Table 1) when compared to other materials such as sugar cane residues ( 8\%) [42] and different clones of Eucalyptus spp. (3 to $5 \%$ ) [36]. The presence of elevated quantity of extractives is a characteristic in advance for energy production, due to its effects in the material's calorific power [43, 44]. MEDEIROS, OLIVEIRA and PAES [45] say that the presence of extractives in the wood is an important characteristic when aiming to produce charcoal, because those increase the wood's density and favor the production of a denser charcoal.

Our results for volatile materials content and fixed carbon are similar to those found by NOGUEIRA et al. [12], they also have studied the charcoal from $B$. excelsa's fruit shell, produced in a metallic oven (barrel type) without temperature control. These authors, however, observed an ash content of only $0.87 \%$, that is $33 \%$ smaller than what we have seen in this study. This difference can be explained by the mineral composition of the soil, that has potassium, calcium, iron, sulfur, phosphorus, magnesium, sodium, among others as 
components. These minerals may be assimilated by the plants and deposited in cell-wall, during its formation or even being present in the pores of the fruit shell in the moment they felt in the ground before being collected for commercialization. Both ash content from the charcoal of fruit shell and tegument of B. excelsa are close to the values found in the literature for other carbonized residues, they varied from 3 to $6 \%$ [46, 47].

The charcoal's gravimetric yield of fruit shells was high when compared to data found in the scientific literature. NOGUEIRA et al. [12] and ANDRADE et al. [48] evaluated the gravimetric yield from the charcoal of B. excelsa H.B.K. and Cocos nucifera L. and they observed values of 25.92 and $32.75 \%$, respectively. The gravimetric yield of the charcoal produced from the tegument was even higher, overcoming the results seen for woods that have been traditionally used for charcoal's production, such as Eucalyptus sp. with $35 \%$ of gravimetric yield [49].

As for the charcoal's calorific power, we have observed higher values then the ones seen by VALE et al. [7] when studying the charcoal produced from residues of Jatrophacurcas spp. SILVA et al. [50], has seen values of $6415 \mathrm{kcal} . \mathrm{kg}^{-1}$ for the charcoal produced from residues of Manikara spp, a tropical specie with high density. When we compare the energetic gains in the carbonization process, we verify that the $B$. excelsa's fruit shell has had gains of about $70 \%$ in HHV, followed by the charcoal produced from L. pisonis's fruit shell $(52 \%)$ and charcoal produced from B. excelsa's fruit tegument (43\%).

The fixed carbon yield is the parameter that better express the energetic quality of the lignocellulosic raw material used for producing charcoal [51], since these variable covers characteristics of productivity and quality, expressing the percentage of fixed carbon in relation to the gravimetric yield after the process. That said, our results evidence that the charcoal produced from the fruit's tegument of B. excelsa has shown better quality, when compared to the other raw material studied.

Despite the gains in the carbonization process, other process such as the pelletizing and briquetting can be evaluated to be used with the fruit tegument of $B$. excelsa, due to its density. The usage of other biomass as raw material, such as residues of Pinus spp., for the production of pellets [52] and of Eucalyptus spp., cotton and rice husk for producing briquettes [5] has demonstrate that agroforestry systems' residues such as the fruits tegument of $B$. excelsa can also be energetically utilized in products of higher aggregated value. This process of energetic densification uses raw materials of less density and high lignin content, which works as a natural adhesive, increasing the product's mechanical resistance. However, we are still studying how to evaluate the quality of briquettes produced from this kind of residue. The differences seen for the majority of the variables expresses the need for more specific studies for each type of residue. Even residues from the same material, as in the case of $B$. excelsa's fruit shell and tegument, has demonstrate significant different results.

\subsection{Correlation matrix}

It can be observed that the greater lignin content is strongly and positively associated with the greatest content of fixed carbon, HHV and fixed carbon and gravimetric yields (Figure 4). Those characteristics are the most important when evaluating the energetic potential of biomasses. A strong and negative correlation has also been observed between charcoal's density and its content of volatile materials. This allows us to infer that residues with higher lignin content, as the fruit tegument of $B$. excelsa, will produce charcoal of high energetic quality, however with low apparent density.

The positive relationship between lignin content and charcoal's gravimetric yield exists due to the high resistance that lignin has to thermal degradation and also because of its complexity as a polymer [53]. The most lignified biomass will result in a higher production of charcoal with elevated calorific power, due to the fastest degradation of the chemical compounds rich in oxygen, such as the cellulose and hemicelluloses [54]. REIS et al. [55] has found a correlation (+0.77) between the gravimetric yield in charcoal and its fixed carbon for the wood of Eucalyptus urophylla. The observed association for the same variables in our study was stronger (+0.97), which can indicate that for non-wood products the charcoal's yield and fixed carbon yield are more correlated.

Our results for the inverse association between lignin content and charcoal's apparent density differ from the ones found by PEREIRA et al. [36] and ARAÚJO et al. [37], but are in accordance with those found by SANTOS et al. [56]. This diversity of results in the literature points that this correlation may or may not exist, depending on other characteristics of the material. This can be explained by the fact that the density is a product of other wood characteristics, such as its chemistry and anatomy which can be highly influenced, varying up or down, while the lignin content remains relatively constant.

The lignin is located mainly in the medium lamella, with less content in the secondary wall [57] while the wood's density is defined mainly by the mass present in the secondary wall, which is more representative between lignocellulosic materials. Thus, biomasses with high lignin content and thinner cellular wall (less 
lignified secondary wall) can result in charcoal with lower apparent density. This is probably the case of $B$. excelsa's fruit tegument charcoal. But for wood such as Eucalyptus spp., the process of lignification is different in adult trees, and because of that we have more lignified wood generating denser charcoal.

The positive correlation between charcoal's gravimetric yield and lignin, and negative between charcoal's gravimetric yield and density implies that the most important variable affecting the charcoal's production in volume is in fact the lignin content. MOUTINHO et al. [58] have seen that greater the charcoal's density, the greater will be its gravimetric yield. However, as in the hypothesis above, the density is a function of many different variables, in the opposite direction of lignin content. So, the greater lignin content implies in more mass at the end of the pyrolysis, this is due to the lignin's thermal resistance.

We have noticed a negative correlation (-0.97) between the gravimetric yield and the holocellulose content. These chemical components are completely degraded in temperatures superior to $400{ }^{\circ} \mathrm{C}$. Similar results were related by VITAL et al. [59], VALE et al. [60] and PROTÁSSIO et al. [61].

As for the charcoal's calorific power and fixed carbon yield, we were able to notice that other two important energetic variables have a strong and negative correlation with the ash content and biomass' extractives, being the greater the content of components with small molecular weight and/or inorganic in biomass, smaller will be the quantity and energy time spent by charcoal's mass unit. This is particularly important when deciding which collecting method to use, as well as for the preparation of this material for carbonization, this is why it is strictly necessary to use materials without any soil residue or any other unknown residue mixed within the biomass.

VELLA et al. [62] affirm that the fixed carbon content is dependent to the values of volatile material and ashes, once it is obtained by the difference in summation of those parameters to 100. According to OLIVEIRA et al. [63], the fixed carbon yield has demonstrated to have a direct relationship with lignin and extractives content, moreover it is inversely proportional to holocellulose content. We also have noticed that the extractives content has an inversely proportional relationship with the fixed carbon yield. Extractives largely varies in their chemistry composition, this could or could not have effects in the fixed carbon yield. Generally, the fixed carbon content is positively influenced by the hydrogen content in the material and negatively influenced by the oxygen content [55]. Thus, extractives that are rich in oxygen, can negatively affect the fixed carbon content, as observed in the correlation. The correlation analysis allows us to evaluate which of the variables has a better relationship with the quality of the product (Figure 3). 


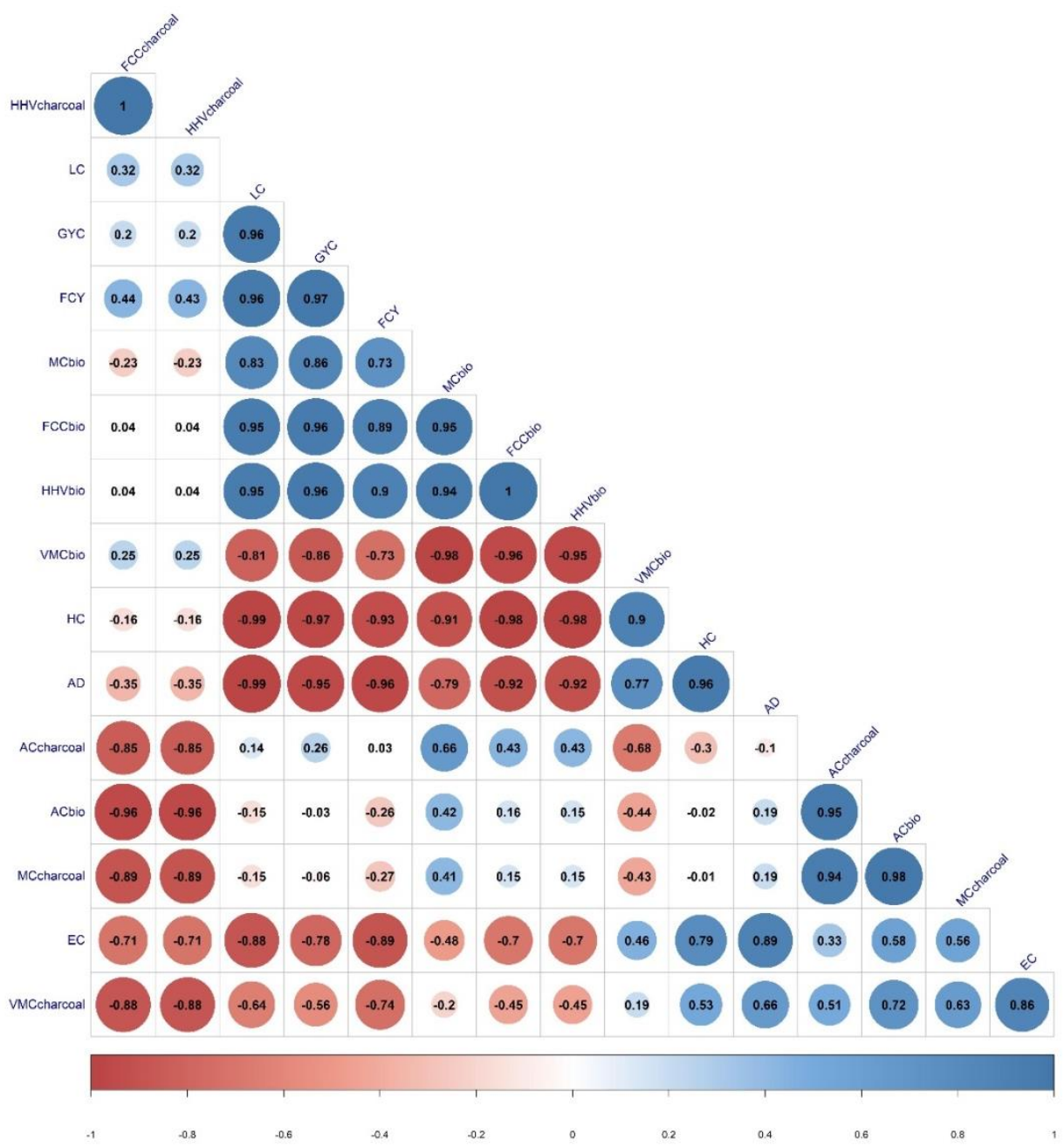

Figure 3: Correlation matrix for all 16 variables studied for the chemical-energetic characterization of the biomass and charcoal from residues of Bertholletia excelsa and Lecythis pisonis. FCC = Fixed Carbon Content, HHV = High Heating Value, $\mathrm{LC}=$ Lignin Content, EC = extractive content, GYC = Gravimetric Yield Charcoal, FCY = Fixed Carbon Yield, $\mathrm{MC}=$ Moisture Content, $\mathrm{VMC}=$ Volatile Materials Content, $\mathrm{HC}=$ Holocellulose Content, $\mathrm{AD}=$ Apparent Density, AC $=$ Ash Content, bio $=$ biomass.

\section{CONCLUSIONS}

Our results evidence that the B. excelsa's fruit shell had shown the presence of condensed tannins through the thin layer chromatography method. New methods for extraction and quantification are still to be tested for this type of residues. The evaluated residues had a high content of lignin and extractives when compared to other types of biomass. The observed correlations allow us to conclude that similar residues, with high content of lignin, fixed carbon and calorific power will result in energetic products of high yield, efficiency and energetic quality, as long as they have low moisture content, ashes content and volatile material content. Those can be used as essential characteristics in the technological evaluation of these materials. Our results show the usage potential for the residues left by the agroforestry systems in the amazon region; $B$. excelsa's fruit shell and tegument both in the production of biopolymers and as well as for the production of products with more aggregated value, such as pellets, briquettes, biochar and activated charcoal.

\section{ACKNOWLEGDMENT}

We thank the sellers at the lower amazon supply center (Mercadão 2000 fair) for the donation of the residues of fruit's shell and teguments utilized in this study. We also thank the wood technology laboratory (LTM) from Federal University of Western Pará (UFOPA) for support in this research. 


\section{BIBLIOGRAPHY}

[1] SANTIAGO, F.L.S., REZENDE, M.A., "Aproveitamento de resíduos florestais de Eucalyptus spp na indústria de fabricação de celulose para geração de energia térmica e elétrica", Energ. Agric, v. 29, n. 4, pp. 241-253, dez. 2014.

[2] BRASIL. Decreto ${ }^{\circ} 5.975$ de 30 de novembro de 2006. Regulamenta os arts. 12, parte final 15, 16, 19, 20 e 21 da Lei no 4.771, de 15 de setembro de 1965, o art. $4^{\circ}$, inciso III, da Lei no 6.938, de 31 de agosto de 1981 , o art. $2^{\circ}$ da Lei no 10.650 , de 16 de abril de 2003, altera e acrescenta dispositivos aos Decretos $\mathrm{n}^{\text {os }}$ 3.179, de 21 de setembro de 1999, e 3.420, de 20 de abril de 2000, e dá outras providências. Disponível em http://www.planalto.gov.br/ccivil_03/_ato2004-2006/2006/decreto/d5975.htm. Acessado em março de 2021.

[3] PEDROZO, E.A., SILVA, T.N., SATO, S.A.S., et al., "Produtos florestais não madeiráveis (PFNMS): as filières do açaí e da castanha da Amazônia", Revista de Administração e Negócios da Amazônia, v. 3, n. 2, 2011.

[4] SONEGO, M., MADIA, M., EDER, M., et al. "Microstructural features influencing the mechanical performance of the Brazil nut ( Bertholletia excelsa ) mesocarp", Journal of the Mechanical Behavior of Biomedical Materials, v. 116, 2021.

[5] DIAS, J.M.C.S., SANTOS, D.T., BRAGA, M., et al. Embrapa Agroenergia: Produção de briquetes e péletes a partir de resíduos agrícolas, agroindustriais e florestais, In: EMBRAPA - Empresa Brasileira de Pesquisa Agropecuária, Brasília, DF, 2012.

[6] PROTÁSIO, T.P., BUFALINO, L., TONOLI, G.H.D., et al., "Relação entre o poder calorífico superior e os componentes elementares e minerais da biomassa vegetal", Pesquisa Florestal Brasileira, v. 31, n. 66, pp. 122-133, 2011.

[7] VALE, A.T., MENDES, R.M., AMORIM, M.R.S., et al. "Potencial energético da biomassa e carvão vegetal do epicarpo e da torta de pinhão manso (Jatropha curcas)", Cerne, v. 17, n. 2, pp. 267-273, 2011.

[8] PEREIRA, D.T.O., NOBRE, J.R.C., BIANCHI, M.L., "Energy quality of residues from Brazil nut (Bertholletia excelsa), in the state of Pará", Brazilian Journal of Development, v. 5, n. 4, pp. 3258-3265, 2019.

[9] LIMA, M.D.R., PATRÍCIO, E.P.S., JUNIOR, U.O.B., et al. "Logging wastes from sustainable forest management as alternative fuels for thermochemical conversion systems in Brazilian Amazon", Biomass and Bioenergy, v. 140, 2020.

[10] MEDEIROS, L.L., SILVA, F.L.H., SANTOS, S.F.M., et al. "Bioconversão do bagaço de pedúnculo de caju hidrolisado para produção de etanol e xilitol", Revista Brasileira de Engenharia Agrícola e Ambiental, v. 21, n. 7, pp. 488-492, 2017.

[11] MORBECK, F.L., LELIS, R.C.C., SCHUELER, M.V.E., et al. "Extraction and evaluation of tannin from green coconut mesocarp", Revista Matéria, v. 24, n. 3, 2019.

[12] NOGUEIRA, R.M., RUFFATO, S., CARNEIRO, J.S., et al. "Avaliação da Carbonização do Ouriço da Castanha-do-Brasil em Forno Tipo Tambor”, Scientific Electronic Archives, v. 6, pp.7-17, 2014.

[13] ASTM D1107 - 96 (2013), Standard Test Method for Ethanol-Toluene Solubility of Wood, West Conshohocken, USA: American Society for Testing and Materials.

[14] ASTM D1106 - 96 (2013), Standard Test Method for Acid-Insoluble Lignin in Wood, West Conshohocken, USA: American Society for Testing and Materials.

[15] TRUGILHO, P.F., SILVA, D.A., "Influência da temperatura final de carbonização nas características físicas e químicas do carvão vegetal de jatobá (Himenea courbaril L.)", Scientia Agraria, v. 2, n. 1-2, 2001, Universidade Federal do Paraná. Paraná, 2001.

[16] ABNT - Associação Brasileira de normas técnicas (1997): NBR 7190 - Projetos de estruturas de madeira, Rio de Janeiro.

[17] ASTM Standard D1762 - 84 (2007), Standard Test Method for Chemical Analysis of Wood Charcoal, Philadelphia, USA: American Society for Testing and Materials.

[18] ABNT (1984): NBR 8633 - Charcoal determination of calorific value test method. Brazilian Association of Technical Standards, Rio de Janeiro.

[19] R CORE TEAM, R: A language and environment for statistical computing, R Foundation for Statistical Computing, Vienna, Austria, http://www.R-project.org/. Acessado em janeiro de 2019.

[20] FRANZBLAU, A., "A primer of statistics for non-statisticians", Oxford, England: Harcourt, Brace, Cap. 7,1958 . 
[21] LOUSADA JÚNIOR, J.E., NEIVA, J.N., RODRIGUEZ, N.M., et al. "Consumo e digestibilidade aparente de subprodutos do processamento de frutas em ovinos", Revista Brasileira de Zootecnia, v.34, n. 2, pp. 659-669, 2005

[22] VÁZQUEZ, G., GONZÁLEZ-ALVAREZ, J., SANTOS, J., et al. "Evaluation of potential applications for chestnut (Castanea sativa) shell and eucalyptus (Eucalyptus globulus) bark extracts", Ind Crop Prod.; v. 29, n. 3, pp. 364-370, 2009.

[23] BATTESTIN, V., MATSUDA, L.K., MACEDO, G.A., "Fontes e aplicações de taninos e tanases em alimentos", Alim. Nutr., v.15, n.1, pp. 63-72, 2004.

[24] PELEGRINO, E.C.F., "Emprego de coagulante à base de tanino em sistema de pós-tratamento de efluente de reator UASB por flotação", Dissertação de M. Sc., USP, Escola de Engenharia de São Carlos, São Carlos, SP, Brasil, 2011.

[25] KLUMB, A.K., FARIA, O.L.V., "Produção de coagulante vegetal catiônico a partir de cascas de eucalipto (Eucalyptus tereticornis)", Vetor, v. 22, pp. 71-80, 2012.

[26] TRUGILHO, P.F., CAIXETA, R.P., LIMA, J.T., et al. "Avaliação do conteúdo em taninos condensados de algumas espécies típicas do cerrado mineiro", Cerne, v. 3, pp. 1-13, 1997.

[27] HAGERMAN, A.E., BUTLER, L.G., "Choosing appropriate methods and standards for assaying tannin”, Journal of Chemical Ecology v. 15, n. 6, pp. 1795-1810, 1989.

[28] HAGERMAN, A.E., ZHAO, Y., JOHNSON, S., Antinutrients and Phytochemicals in Food, 12, 209, 1997.

[29] MONDAL, K.C., BANERJEE, D., JANA, M., et al. "Colorimetric assay for determination of Tannin Acyl Hydrolase (E.C. 3.1.1.20) activity", Anal. Biochem. v. 295, pp. 168-171, 2001.

[30] MUELLER-HARVEY, I., "Analysis of Hydrolysable Tannins", Animal Feed Science and Technology, v. 91, pp. 3-20, 2001.

[31] EFRAIM, P., TUCCI, M.L., PEZOA-GÁRCIA, N.H., et al. "Teores de compostos fenólicos de sementes de cacaueiro de diferentes genótipos", Brazilian Journal of Food Technology, v. 9, n. 4, pp. 229-236, 2006.

[32] AGOSTINI-COSTA, T.S., LIMA, A., LIMA, M.V., "Determinação de taninos em pedúnculo de caju: método da vanilina versus método do butanol ácido", Química Nova, v. 26, n. 5, pp. 763-765, 2003.

[33] ROCHA, W.S., LOPES, R.M., SILVA, D.B., et al., "Compostos fenólicos totais e taninos condensados em frutas nativas do cerrado", Revista Brasileira de Fruticultura, v. 33, n. 4, pp. 1215-1221, 2011.

[34] AZEVÊDO, T.K.B., PAES, J.B., CALEGARI, L., et al. "Teor de Taninos Condensados Presente na Casca de Jurema-Preta (Mimosa tenuiflora) em Função das Fenofases”, Floresta e Ambiente, v. 24, 2017.

[35] PROTÁSIO, T.P., TRUGILHO, P.F., ARAÚJO, A.C.C., et al. "Classificação de clones de Eucalyptus por meio da relação siringil/guaiacil e das características de crescimento para uso energético", Scientia Forestalis, v. 45, n. 114, pp. 327-341, 2017.

[36] PEREIRA, B.L.C., CARNEIRO, A.C.O., CARVALHO, A.M.M.L., et al. "Influence of chemical composition of Eucalyptus wood on gravimetric yield and charcoal properties", BioResources, v. 8, n. 3, pp. 4574-4592, 2013b.

[37] ARAÚJO, A.C.C., TRUGILHO, P.F., NAPOLI, A., et al. "Efeito da relação siringil/guaiacil e de fenóis derivados da lignina nas características da madeira e do carvão vegetal de Eucalyptus spp.", Scientia Forestalis, v. 44, n. 110, pp. 405-414, 2016.

[38] VANDERGHEM, C., RICHEL, A., JACQUET, N., et al. "Impact of formic/acetic acid and ammonia pre-materials on chemical structure and physico-chemical properties of Miscanthus giganteus lignin", Polymer Degradation and Stability, v. 96, pp. 1761-1770, 2011.

[39] ROWELL, R.M., PETTERSEN, R., HAN, J.S., et al. "Handbook of wood chemistry and wood composites", Cell wall chemistry CRC Press, pp. 35-74, 2005.

[40] MÜLLER-HAGEDORN, M., BOCKHORN, H., KREBS, L., et al. "A comparative kinetic study on the pyrolysis of three different wood species", Journal of Analytical and Applied Pyrolysis, v.68, n.1, pp. 231249, 2003.

[41] YANG, H., YAN, R., CHEN, H., et al. "Characteristics of hemicellulose, cellulose and lignin pyrolysis", Fuel, v. 86, pp. 1781-1788, 2007.

[42] MOUTTA, R.D.O., FERREIRA-LEITÃO, V.S., BON, E.P.D.S., "Enzymatic hydrolysis of sugarcane bagasse and straw mixtures pretreated with diluted acid", Biocatalysis and Biotransformation, v. 32, n. 1, pp. 
93-100, 2014.

[43] BUFALINO, L., PROTÁSIO, T.P., COUTO, A.M., et al. "Caracterização química e energética para aproveitamento da madeira de costaneira e desbaste de cedro australiano", Brazilian Journal of Forestry Research, v. 32, n. 70, pp. 129-137, 2012.

[44] CASTRO, A.F.N.M., CASTRO, R.V.O., CARNEIRO, A.C.O., et al. "Análise multivariada para seleção de clones de eucalipto destinados à produção de carvão vegetal", Pesquisa Agropecuária Brasileira, v. 48, n. 6, pp. 627-635, 2013.

[45] MEDEIROS, P.N., OLIVEIRA, L., PAES, J.B., "Relações entre as características da madeira e do carvão vegetal de duas Espécies da Caatinga", Floresta e Ambiente, v. 21, n. 4, pp. 484-493, 2014.

[46] SOARES, L.S., MORIS, V.A.S., YAMAJI, F.M., et al. "Utilização de resíduos de borra de café e serragem na moldagem de briquetes e avaliação de propriedades", Matéria (Rio Janeiro), v. 20, n. 2, pp. 550-560, 2015.

[47] VALE, A.T., MIGUEL, E.P., MOREIRA, A.C.O., et al. "Artificial neural networks in predicting energy density of Bambusa vulgaris in Brazil", African Journal of Agricultural Research , v. 12, pp. 856-862, 2017.

[48] ANDRADE, A.M., PASSOS, P.R.A., MARQUES, L.G.C., et al. "Pirólise de resíduos do coco-da-baía (Cocos nucifera linn) e análise do carvão vegetal", Revista Árvore, v. 28, n. 5, pp. 707-714, 2004.

[49] OLIVEIRA, A.C., CARNEIRO, A.D.C.O., VITAL, B.R., et al. "Efeito da qualidade da madeira sobre o rendimento e qualidade do carvão de Eucalyptus grandis", Revista Árvore, v. 13, n. 1, pp. 85-97, 1989.

[50] SILVA, M.G., NUMAZZAWA, S., ARAUJO, M.M., et al. "Carvão de resíduos de indústria madeireira de três espécies florestais exploradas no município de Paragominas, PA", Acta Amazônica, v. 37, n. 1, pp. 61-70, 2007.

[51] VITAL, B.R., ANDRADE, A.M., VALENTE, O.F., et al. "Influência da casca no rendimento e qualidade de carvão vegetal de Eucalyptus grandis", Scientia Forestalis, n. 41/42, pp. 44-49, 1989.

[52] SPANHOL, A., NONES, D.L., KUMABE, F.J.B., et al. "Qualidade dos pellets de biomassa florestal produzidos em Santa Catarina para a geração de energia”, Floresta, v. 45, n. 4, pp. 833-844, 2015.

[53] BRITO, J.O., BARRICHELO, L.E.G., "Correlações entre as características físicas e químicas da madeira e a produção de carvão vegetal: densidade e teor de lignina da madeira de eucalipto", IPEF, n.14, pp.9-20, 1977.

[54] PEREIRA, B.L.C., CARNEIRO, A.C.O., CARVALHO, A.M.M.L., et al. "Influenceof chemical composition of Eucalyptus wood on gravimetric yield and charcoal properties", BioResources, v. 8, n. 3, pp. 45744592, 2013.

[55] REIS, A.A, PROTÁSIO, T.P, MELO, I.C.N.A., et al. "Composição da madeira e do carvão vegetal de Eucalyptus urophylla em diferentes locais de plantio", Pesquisa Florestal Brasileira, v. 32, n. 71, pp. 277290, 2012.

[56] SANTOS, R.C., CARNEIRO, A.C.O., CASTRO, A.F.M., et al. "Correlações entre os parâmetros de qualidade da madeira e do carvão vegetal de clones de eucalipto", Scientia Forestalis, v. 39, n. 90, pp. 221230, 2011.

[57] ZHENG, Y., ZHAO, J., XU, F., et al. "Prematerial of lignocellulosic biomass for enhanced biogas production", Progress in Energy and Combustion Science, v. 42, pp. 35-53, 2014.

[58] MOUTINHO, V.H.P., FILHO, M.T., BRITO, J.O., et al. "Influence of the wood physical properties on the charcoal physical and mechanical properties", Sci. For., v. 44, n. 111, pp. 557-561, 2016.

[59] VITAL, B.R., ALMEIDA, J., VALENTE, O.F., et al. "Características de crescimento das árvores e de qualidade da madeira de Eucalyptus camaldulensis para a produção de carvão", IPEF, v. 47, pp. 22-28, 1994.

[60] VALE, A.T., DIAS, I.S., SANTANA, M.A.E., "Relações entre propriedades químicas, físicas e energéticas da madeira de cinco espécies de cerrado", Ciência Florestal, v. 20, n. 1, pp. 137-145, 2010.

[61] PROTÁSIO, T.P., TRUGILHO, P.F., NEVES, T.A., et al. "Análise de correlação canônica entre características da madeira e do carvão vegetal de Eucalyptus", Scientia Forestalis, v. 40, n. 95, pp. 317-326, 2012.

[62] VELLA, M.M.C.F., VALENTE, O.F., VITAL, B.R., et al. "Influência da velocidade de carbonização da madeira nos rendimentos e nas propriedades do carvão produzido", Revista IPEF, n. 41/42, pp. 64-76, 1989.

[63] OLIVEIRA, A.C., CARNEIRO, A.C.O., VITAL, B.R., et al. "Parâmetros de qualidade da madeira e do carvão vegetal de Eucalyptus pellita F. Muell”, Scientia Forestalis, v. 38, pp. 431-439, 2010. 


\section{ORCID}

Iara Nobre Carmona

https://orcid.org/0000-0003-3706-3286

Juliane da Silva Sampaio

https://orcid.org/0000-0003-2861-6571

Pablo Antônio Souza Amorim da Luz

https://orcid.org/0000-0003-0555-4865

Fernando Wallase Carvalho Andrade

https://orcid.org/0000-0001-8728-5536 